\title{
Discrediting experiences: outcomes of eligibility assessments for claimants with psychiatric compared with non-psychiatric conditions transferring to personal independence payments in England - ERRATUM
}

Katie Pybus, Kate E. Pickett, Stephanie L. Prady, Charlie Lloyd and Richard Wilkinson

\section{Keywords}

Service users; parity of esteem; personal independence payments; welfare reform; eligibility assessment; erratum.

\section{Copyright and usage}

(C) The Royal College of Psychiatrists 2019. This is an Open Access article, distributed under the terms of the Creative Commons Attribution licence (http://creativecommons.org/licenses/by/4.0/), which permits unrestricted re-use, distribution, and reproduction in any medium, provided the original work is properly cited.

https://doi.org/10.1192/bjo.2019.3, Published online by Cambridge University Press, 04 February 2019

The publishers regret to announce that the above paper was published with the incorrect article number.

The correct citation details are as follows:

Pybus K, Pickett KE, Prady SL, Lloyd C, Wilkinson R. Discrediting experiences: outcomes of eligibility assessments for claimants with psychiatric compared with non-psychiatric conditions transferring to personal independence payments in England. BJPsych Open 2019; 5(2): e19. https://doi.org/10.1192/bjo.2019.3.

This has now been updated in the original article online.

The publisher sincerely apologises for this error.

\section{Reference}

Pybus K, Pickett KE, Prady SL, Lloyd C, Wilkinson R. Discrediting experiences: outcomes of eligibility assessments for claimants with psychiatric compared with non-psychiatric conditions transferring to personal independence payments in England. BJPsych Open 2019; 5(2): e19. https://doi.org/10.1192/bjo.2019.3. 